
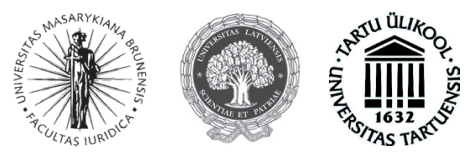

ISSN 1392-6195 (print) ISSN 2029-2058 (online) JURISPRUDENCIJA JURISPRUDENCE 2013, 20(3), p. 1061-1080.

\title{
TEISINGUMAS IR NEŠALIŠKUMAS CIVILINIAME PROCESE
}

\author{
Rūta Petkuvienè \\ Mykolo Romerio universiteto Teisès fakulteto \\ Teisès filosofijos ir istorijos katedra \\ Ateities g. 20, LT-08303 Vilnius, Lietuva \\ Telefonas (+370 5) 2714697 \\ Elektroninis paštas ruta.petkuviene@teismas.lt
}

Pateikta 2013 m. rugsėjo 5 d., parengta spausdinti 2013 m. rugsèjo $20 \mathrm{~d}$.

doi:10.13165/JUR-13-20-3-10

Anotacija. Straipsnyje yra analizuojama, kiek gali büti teisingas standartinis teismo procesas, tiriama, kokiais büdais ir priemonemis yra igyvendinamas teisingumas procesine prasme. Pripažistama, kad teismas, kaip subjektas, sprendžiantis teisini ginča, igyvendina teisinguma tik tuo atveju, jei užtikrina nešališkuma visu asmenu atžvilgiu. Tinkamas teisinis procesas yra konstitucinés teisés kreiptis i teisma sudedamoji dalis. Tačiau procesas nèra paremtas vien teisés principais, kurie inkorporuoja daugiau ar mažiau nusistovejusias nuostatas, ar teisès normomis. Tam tikri konkretūs politiniai sprendimai ar veiksmai turi įtakos teismo procesui.

Straipsniu siekiama išnagrinèti tam tikrus teisingumo principo igyvendinimo aspektus Lietuvos teismu procesuose. Parodoma, kad teisinès metodologijos trükumas lemia skirtingus priimtu sprendimu argumentus, ju nenuspejamuma, todel neskatina teisinès taikos.

Reikšminiai žodžiai: teisès aiškinimas, teismų aktyvumas, teisingumas, nešališkumas, teisine metodologija. 


\section{İvadas}

Iprastai manoma, kad teisingas rezultatas yra tas, kuris pasiekiamas laikantis taisyklių, todèl valstybių, kurių teisinè sistema grịsta kontinentinès teisės tradicija, teismai igyvendina teisingumą pagal nustatytą tvarką, t. y. proceso įstatymus. Vienas iš proceso įstatymų tikslų yra ginti asmenų teises ar ịstatymų saugomus interesus. Sprendimo priėmimas pagal taisykles užtikrina nešališkumą, sprendimo standartiškumą, o tai prisideda prie nuoseklios teismų praktikos formavimosi, sprendimų nuspejjamumo, leidžia išvengti spekuliacijų dẻl teismo priklausomumo. Kita vertus, kyla pavojus, jog standartiniai sprendimai bus palankūs tik vienos tam tikros asmenų grupès, esančios politinėje valdžioje, interesų užtikrinimo tikslui. Tuomet kyla klausimas, ar nereikètų teismams suteikti daugiau veiksmų laisvès? Tačiau tai padarę turime būti pasirengę modifikuoti arba pritaikyti ịsitikinimus dèl laisvesnio taisyklių taikymo, atsisakant nuomonès, jog tik standartinis teismo procesas yra teisingas ${ }^{1}$.

Pusiausvyros metodas visais atvejais siejamas su teisingumo igyvendinimu. Jo pagrindu formuojama principų struktūra. Nepaisant metodologijos, nebelieka nuoseklaus principų rinkinio. Pripažistama, kad Lietuvoje buvo sukurtos doktrininès prielaidos didelei teismų laisvei, teismams teikiant argumentus ir patiems nusistatant savo kompetencijos apimtį ${ }^{2}$. Teismui akceptavus veiksmų laisvès principą be aiškios metodologijos, turime būti pasirengę atsisakyti visų mūsų ịsitikinimų apie teisingumą, kurie paremti ankstesniais nepriklausomais autoritetais.

Taigi kyla būtinybė apsvarstyti šias situacijas, kad būtume pakankamai ịsitikinę, ar pasieksime norimą rezultatą - asmens teisių ir interesų pusiausvyrą, todèl šiame straipsnyje, taikant lyginamajị, analitinị ir sisteminị metodus, tiriamas teismo proceso socialinis veiksmingumas teismui taikant dvi teisingumo koncepcijas ir ieškant optimalaus jų santykio.

Šio straipsnio tikslas yra ištirti teisingumo (nešališkumo) igyvendinimo civiliniame procese aspektus, teismams atliekant šio principo aiškinimą. Straipsnio objektas yra asmens teisè ị nešališką teismą kaip procesinio pobūdžio garantija. Jame keliama hipotezè, kad teismai, privalantys garantuoti rungtyniškumą, dèl pernelyg didelio savo aktyvumo ir laisvo proceso įstatymo interpretavimo gali nepagrịstai jị pažeisti, tuo pažeisdami ir lygiateisiškumą bei kitus proceso principus. Straipsnis yra aktualus tuo, kad iki šiol mokslinèje literatūroje nebuvo nuodugniau nagrinèjama, kokie nešališkumo aspektai atsiskleidžia konkrečiose bylose šiandienos teismų praktikoje, kaip tai veikia visuomenès požiūrị ị teisingumą.

Apie kitus teisės į teisingą procesą aspektus, tokius kaip reikalavimo užtikrinti teismo nepriklausomumą nuo politinès valdžios įtakos, teisès ị teisingą procesą teorinius aspektus, rašè E. Jarašiūnas, V. Mikelènas, V. Sinkevičius, A. Abramavičius, todèl šiame straipsnyje yra nagrinėjamos minètų autorių neanalizuotos praktinès sąlygos ịgyven-

1 Dworkin, R. Rimtas požiūris ị teises. Vilnius: Lietuvos rašytojų sajungos leidykla, 2004, p. 230.

2 Lastauskienè, G. Teisè v. teisè arba teismų ,interpretacinis žaismas“ ir jo doktrininès prielaidos. Jurisprudencija. 2012, 19 (4): 1343-1359. 
dinant teisę i tinkamą teismo procesą. Apie teismų aktyvumo formas ir iš to kylančias problemas rašè G. Lastauskienè, o šiuo straipsniu siekiama pratęsti teisinę diskusiją, ją papildant nešališkumo aspekto analize.

\section{Nešališkumo teisinis reglamentavimas}

Konstruktyvusis teisingumo modelis reikalauja, kad sprendimai, priimami apeliuojant ị teisingumą, būtų teisiškai pagrịsti, atsižadant bet kokių teisėjo subjektyvių ịsitikinimų ir išankstinių nuostatų. Tokio sprendimo prièmimą užtikrina proceso normos, kurių igyvendinimas sudaro sąlygas priimti sprendimą, nepriklausomą ne tik nuo ịsitikinimų, bet ir politinès valios, kitų asmenų ịtakos. Taigi konstruktyvusis modelis dèl šios priežasties yra patrauklus. Taip pat jis gerai tinka teisingumo problemas svarstant grupès požiūriu, t. y. plètojant teoriją, kurią galima laikyti bendruomenès, o ne atskiru individų teorija ${ }^{3}$, ir tai reikia suvokti sprendžiant bylas. Taigi konstruktyviojo teisingumo koncepcija inkorporuoja bendrus bendruomenès ịsitikinimus, todèl pagal ją grindžiant nagrinèjamą bylą nepaisoma individo teisingų pastebėjimų. Tokiu atveju nėra priimamas kompromisinis sprendimas.

Jeigu teismo procese būtų paisoma individualaus teisingumo suvokimo, priimtą sprendimą kvestionuotų reliatyvizmo formos, nes visuomet iškiltų klausimas, kiek jis nuodugnus (patikimas) ir moralus. Tokių sunkumų išvengtume, jei būtų laikomasi konstruktyviojo modelio, tačiau atkreiptinas dėmesys ir į tai, kad individualus teisingumo aktas paprastai nėra visuomenei naudingas, tačiau ,visa schema $<_{\text {... }}>$ yra visuomenei naudinga“"4. Bene priimtiniausia būtų tokia interpretacija: asmuo yra suinteresuotas priimto sprendimo vykdymu, prievartos mechanizmas - nereikalingas.

Nešališkumo standartas pasiekiamas, jei laikomasi vieno atskaitos taško, t. y. tuomet, kai visų elgesys yra saistomas tam tikrų universaliai taikomų taisyklių. Jei visi žmonès natūraliai siektų viešosios naudos, jiems niekada nekiltų mintis, kad būtina vienas kitą riboti teisingumo taisyklėmis, tačiau Hume'o nuomone, tai neịmanoma, nes visuomet veikia savanaudiškumo sąlyga. B. Barry papildo, kad, be kita ko, gali būti neatitikimas net tarp viešo intereso (iš kurio laimi visi) ir viešosios naudos (grynosios naudos sudèjus visų naudingumus) ${ }^{5}$.

Pirmoji nešališkumo pakopa reikalauja taisykles visiems taikyti vienodai: visi prieš įstatymą yra lygūs ${ }^{6}$. Taigi teisèjas turi būti nešališkas ir šalis traktuoti lygiai. Lietuvos Respublikos Konstitucijos 31 straipsnio 2 dalimi asmenims laiduojama teisè ị nepriklausomą ir nešališką teismą ${ }^{7}$. Lietuvos Respublikos teismų įstatymo 3 straipsnio 2 dalis

3 Dworkin, R., supra note 1, p. 235.

4 Rawls, A. Theory of Justice. Cambridge, Mass.: Harvard University Press, 1971, p. 510.

5 Barry, B. Teisingumo teorijos. Vilnius: Eugrimas, 2002, p. 183.

6 Höffe, O. Gerechtigkeit. München: Beck, 2001, p. 11.

7 Lietuvos Respublikos Konstitucija, Lietuvos Respublikos piliečių priimta 1992 m. spalio 25 d. referendume. Valstybès žinios. 1992, Nr. 33-1014. 
numato, kad teisėjai, vykdydami teisingumą, veikia nešališkai ir klauso tik įstatymų ${ }^{8}$. Proceso įstatymai taip pat numato principus, kuriais vadovaujantis igyvendinamas nešališkumas. Lietuvos Respublikos civilinio proceso kodekso (toliau-CPK) 6 straipsnis numato, jog teisingumą civilinèse bylose vykdo tik teismai vadovaudamiesi asmenu lygybès įstatymui ir teismui principu. Minèto ịstatymo 9 straipsnis reglamentuoja teismo posėdžio viešumo reikalavimą, rungimosi principo taikymą (12 straipsnis), betarpiškumo reikalavimą, kuris ịpareigoja teismą ištirti visus byloje esančius ịrodymus (14 straipsnis) $)^{9}$. Kaip matyti iš Lietuvoje įstatymais nustatyto reguliavimo, laikoma, kad bylinèjimasis pagal teisingo proceso reikalavimus užtikrina teisingumą (nešališkumą).

Teisė ì nešališką teismą yra viena pagrindinių žmogaus teisių, ginamų tiek nacionaliniu, tiek tarptautiniu lygmeniu (Žmogaus teisių ir pagrindinių laisvių apsaugos konvencijos 6 straipsnio 1 dalis). Lietuvos Respublikos Konstitucinis Teismas 2001 m. vasario $12 \mathrm{~d}$. nutarime yra konstatavęs, kad asmens konstitucinė teisè, jog jo bylą išnagrinètų nešališkas teismas, reiškia tai, kad asmens bylos negali nagrinèti teisèjas, dèl kurio nešališkumo gali kilti abejonių; teisèjas, nagrinèjantis bylą, turi būti neutralus; teismo nešališkumas, kaip ir teismo nepriklausomumas, yra esminè žmogaus teisių ir laisvių užtikrinimo garantija, būtina teisingos bylos išnagrinejjimo, pasitikejjimo teismu sąlyga $^{10}$. Nešališkumo klausimu išplètota Europos Žmogaus Teisių Teismo (toliau Teismas) praktika yra kruopščiai analizuojama Lietuvos teismų, bylose šalinant tiek subjektyvujị, tiek objektyvųji kriterijų ${ }^{11}$.

\section{Teisingumas ir nešališkumas ieškinio teisenos bylose}

Kaip minėta, Lietuvoje tiek teisès teoretikų, tiek praktikų pripažịstama, kad buvo sukurtos doktrininės prielaidos didelei teismų laisvei. Teisėjų veiksmų laisvė grindžiama siekiu užtikrinti didesnę vienos iš visuomenès grupių teisių apsaugą, t. y. neleisti vieniems subjektams dominuoti kitų atžvilgiu, šalinat šalių nelygybę. Taip pat teisèjų veiksmų laisvė pateisinama siekiu priimti teisingą sprendimą. Taigi iškyla klausimas, kaip tai suderinama su standartiniu teismo procesu, turinčiu vykti griežtai pagal procesines nuostatas, išdèstytas įstatyme ir dẻl to užtikrinančias teisingą teisinị procesą?

Civilinis procesas yra skirtas asmenų, kurių materialinės subjektinès teisès ar įstatymų saugomi interesai pažeisti ar ginčijami, interesams ginti, tinkamai taikant įstatymus teismui nagrinejjant civilines bylas, priimant sprendimus ir juos vykdant (CPK 5 straipsnis). Remdamiesi šia norma, kai kurie autoriai interpretuoja, jog teismas, be kita

8 Lietuvos Respublikos teismų ịstatymas. Valstybés žinios. 1994, Nr. 48-851.

9 Lietuvos Respublikos civilinio proceso kodeksas. Valstybès žinios. 2002, Nr. 36-1340; Valstybès žinios. 2002, Nr. 42.

10 Lietuvos Respublikos Konstitucinio Teismo $2001 \mathrm{~m}$. vasario 12 d. nutarimas „Dėl Lietuvos Respublikos advokatūros įstatymo 26 straipsnio 3 ir 4 dalių atitikimo Lietuvos Respublikos Konstitucijai“. Valstybés žinios. 2001, Nr. 14-445.

11 Pvz., Lietuvos Aukščiausiojo Teismo Civilinių bylų skyriaus teisèjų kolegijos 2013 m. vasario 22 d. nutartis civilineje byloje R. M. v. O. J. M. ir L. V. M., bylos Nr. 3K-3-12/2013; 2012 m. spalio 31 d. nutartis civilinèje byloje $A B$ „Panevéžio energija“ v. AB „Diskontas“, bylos Nr. 3K-3-154/2012 ir kt. 
ko, yra atsakingas už žmogaus teisių gintị ${ }^{12}$. Tačiau yra ir priešinga nuomonè, kad civiliniame procese būtent šalys yra tiesiogiai atsakingos už savo teisių gynimą, siekdamos išvengti nepalankaus sprendimo ${ }^{13}$.

Istatyme įtvirtinti šalių dispozityvumo ir rungimosi principai leidžia šaliai pasirinkti jai priimtiniausią savo teisių ir teisètų interesų gynimo būdą. CPK 135 straipsnio 1 dalies 4 punktas numato, kad ieškovai turi suformuluoti ieškinio dalyką, minèto straipsnio 1 dalies 2 punktas reikalauja ieškinị pagrịsti. Lietuvos Aukščiausiasis Teismas formuoja teismų praktiką, kad tuo atveju, jei šalies pateikiamas procesinis dokumentas neatitinka isstatymo reikalavimų, teismas nutartyje dẻl ieškinio trūkumų turètų išvardyti šalintinus trūkumus ir nurodyti jų šalinimo būdus visais atvejais, net jei bylą šalis veda per atstovą profesionalą - advokatą. Toks aiškinimas yra grindžiamas keliais argumentais. Vienas iš jų - teismas, spręsdamas ieškinio prièmimo klausimą, privalo užtikrinti, kad būtų laikomasi įstatymo reikalavimų, nustatančių teisès kreiptis ị teismą igyvendinimą, nes priešingu atveju, be pagrindo iškèlus bylą, gali būti pažeistos kitų šalių teisès, kadangi asmuo, igyvendindamas savo teisę ne pagal jos socialinę paskirtį, daro žalą kitiems asmenims ${ }^{14}$. Taigi teismas negali apsiriboti formalių kriterijų, tokių kaip teismingumo, žyminio mokesčio sumokèjimo, igaliojimų ir pan., patikrinimu, bet ir išsamiai ịvertinti procesinio dokumento turinị.

Lieka išsiaiškinti, ką reiškia vertinti procesinio dokumento turinị. Be kita ko, teisejjas tai turi padaryti jau spręsdamas klausimą dèl jo prièmimo (CPK 115, 135 straipsniai). Kyla du galvosūkiai. Ar teisèjas ịpareigojamas iš karto vertinti ginčo esmę ir pagal tai ịpareigoti šalinti trūkumus? Kitas: ar apsiriboti bendru reikalavimu išsamiau nurodyti aplinkybes ir ịrodymus, o po to, nenukrypstant nuo šalių nurodytos ginčo esmès, spręsti bylą?

Iš minėtos Lietuvos Aukščiausiojo Teismo nutarties būtų galima spręsti, jog būtina ịvertinti, ar apskritai ginčijama teisė priklauso asmeniui, ar nėra aplinkybių, paneigiančių faktinį reikalavimo pagrindimą. Tačiau jei taip yra, reikia atsakyti ị principinị klausimą, ar tokiu atveju nėra atliekamas išankstinis bylos vertinimas dẻl jos perspektyvos ir ar tai yra teisinga, nes, atsisakius priimti ieškinị, net ir prasidejjus apeliaciniam procesui, nebus išklausyta kita pusè. Ši situacija dar labiau komplikuojasi, jei iškyla šališkumo klausimas, nes tik taisyklių visumos taikymas užtikrina procedūrini teisingumą.

Situacija dèl reikalavimo teismui nurodyti konkrečius ieškinio trūkumus, tarp jų ir kokius reikalavimus ieškovas turi reikšti, kad ieškinio tenkinimas objektyviai sukurtų teisinius padarinius, nurodyti, kokias aplinkybes būtina nustatyti, kad būtų teisingai išnagrinèta byla ${ }^{15}$, gali būti suprantama kaip dispozityvumo pažeidimas, nes priešinga

12 Stauskienė, E. Konstitucinès justicijos įtaka Lietuvos civilinio proceso teisei. Jurisprudencija. 2012 , 19 (3): 1084.

13 Rosenberg, L.; Schwab, H. K.; Gottwald, P. Zivilprozessreecht. 15. Aufl. Munchen: Verlag C. H Beck, 1993, p. 669-670.

14 Lietuvos Aukščiausiojo Teismo Civilinių bylų skyriaus teisejjų kolegijos $2009 \mathrm{~m}$. balandžio 27 d. nutartis civilinèje byloje $V$. K. v. D. K., Marijampolès apskrities viršininko administracija, bylos Nr. 3K-3-181/2009.

15 Lietuvos apeliacinio teismo $2009 \mathrm{~m}$. gruodžio $21 \mathrm{~d}$. nutartis civilinèje byloje $R$. T. v. V. K., bylos Nr. 2A$675 / 2009$. 
šalis gali susidaryti ịspūdị dèl teismo tendencingumo. Tuomet, siekiant išlaikyti šalių teisių pusiausvyrą, jų lygiateisiškumą, lygiai taip pat reikètų padèti atsakovui suformuluoti atsikirtimus. Taigi susiklosto situacija, kad teismas, privalėdamas aktyviai veikti, kad užtikrintų greitą, ekonomišką ir sąžiningą procesą ir nesudarytų sąlygų procesui vilkinti, perima šalių pareigą apibrěžti ginčo dalyką. Bet ar tai pateisinama teisingumu, jei laikomès pozicijos, kad tik asmuo turi teisę pasirinkti, kokiam asmeniui ar kokiems asmenims reikšti reikalavimus, kokius reikalavimus jam (jiems) reikšti, kokiomis aplinkybėmis grịsti pareikštus reikalavimus, kokiais įrodymais įrodinèti išdèstytas aplinkybes?

Tačiau iš Lietuvos Aukščiausiojo Teismo praktikos matyti, jog teismas aktyviai turètų spręsti ir tinkamos - turinčios atsakyti pagal ieškini arba turinčios reikalavimą šalies nustatymo klausimą, o tokia teismo priedermè atsiranda jau pasirengimo civilinių bylų nagrinejjimui teisme stadijoje. Be abejo, nurodoma, kad toks teismo aktyvus dalyvavimas byloje turètų vykti nepažeidžiant konstitucinio teismo nešališkumo principo ${ }^{16}$. Ir nors kasacinės instancijos teismas išaiškina, jog teismo pareiga nustatyti tinkamą šalị iš dalies yra ribojamas proceso šalių diapozityviškumas, tačiau žmogui toks teismo aktyvumas sukelia pamąstymus, ar teismas nėra suinteresuotas veikti kitos šalies naudai, juolab kad gramatinè teisès normos išraiška draudžia be šalies sutikimo keisti šalį. Be to, teismas gali pakeisti pradinę šalį tik pagal motyvuotą prašymą ${ }^{17}$. Tokiu atveju iškyla klausimas, ar tokia teisès akto interpretacija yra objektyviai tinkama ir pateisinama teisingumo teorija?

Kasacinès instancijos teismas, aiškindamas CPK 7 straipsnyje įtvirtintų proceso koncentracijos ir ekonomiškumo principų santyki su CPK 45 straipsniu, 230 straipsnio 1 dalimi $^{18}$, 243 straipsniu $^{19}$, nurodè, kad pirmos instancijos teismas privalo išaiškinti šalims teisę pakeisti netinkamą atsakovą bei išaiškinti šalies nepakeitimo procesinius padarinius. Kai teismas to nepadaro, sprendžiama, jog padarytas esminis teisès normų pažeidimas $^{20}$.

16 Lietuvos Aukščiausiojo Teismo Civilinių bylų skyriaus teisèjų kolegijos $2011 \mathrm{~m}$. balandžio 19 d. nutartis civilineje byloje G. L. v. S. D., bylos Nr. 3K-3-186/2011.

17 CPK 45 straipsnio 1 dalis numato, kad teismas, bylos nagrinèjimo metu nustatęs, kad ieškinys pareikštas ne to asmens, kuriam priklauso reikalavimo teisè, arba ne tam asmeniui, kuris turi pagal ieškinį atsakyti, gali vienos iš šalių motyvuotu prašymu, nenutraukdamas bylos, pakeisti pradinị ieškovą arba atsakovą tinkamu ieškovu arba atsakovu. Pagal to paties straipsnio 3 dalį, jeigu ieškovas nesutinka, kad atsakovas būtų pakeistas kitu asmeniu, teismas nagrinèja bylą iš esmès.

18 CPK 230 straipsnio 1 dalis numato, kad posedžio pirmininkas ị parengiamąji teismo posèdị iškviečia šalis ir jas apklausia, siekdamas išsiaiškinti ginčo esmę, galutinai suformuluoti šalių reikalavimų ir atsikirtimų i pareikštus reikalavimus turini, įrodymus, kuriais jos grindžia savo reikalavimus, bei atsikirtimus, ịtrauktinus dalyvauti byloje asmenis ir atlieka kitus veiksmus, kurie, teismo manymu, reikalingi tinkamai išnagrinèti bylą teismo posėdyje.

19 CPK 243 straipsnis numato, kad teismo posėdžio pirmininkas šio Kodekso nustatyta tvarka išaiškina pagal įstatymą šalims, tretiesiems asmenims ir jų atstovams, atvykusiems ị teismo posėdi, jų procesines teises ir pareigas, išskyrus atvejus, kai šalys ar tretieji asmenys bylą veda per atstovą, turintị aukštajį universitetinị teisinị išsilavinimą.

20 Lietuvos Aukščiausiojo Teismo Civilinių bylų skyriaus teisejų kolegijos $2007 \mathrm{~m}$. kovo 15 d. nutartis civilineje byloje Varènos rajono savivaldybè v. Z̆. S. ir kt., bylos Nr. 3K-3-100/2007; Lietuvos Aukščiausiojo Teismo Civilinių bylų skyriaus išplèstinès teisèjų kolegijos $2007 \mathrm{~m}$. lapkričio $26 \mathrm{~d}$. nutartis civilinėje byloje L. B. ir kt. v. daugiabučio namo savininku bendrija ,,Medvégalis “ ir kt., bylos Nr. 3K-7-345/2007; 
Tokia kasacinio teismo praktika, kai pirmosios instancijos teismui buvo numatyta pareiga visais atvejais nustatinėti tinkamą šalị, paskatino teismą koncentruotis ne ị ginčo esmę, o ị šalies procesinės padėties nustatymą, t. y. iki bylos išnagrinėjimo pabaigos jau spręsti, kas turètų atsakyti pagal ieškinị arba kam priklauso reikalavimo teisè, o ne nešališkai nagrinèti ginčą pagal šalies suformuluotą faktinị pagrindą ir pateiktus įrodymus ar suformuluotus atsikirtimus. Nustačius, kad šalis netinkama, ir sutikus ją pakeisti, bylos nagrinėjimas pradedamas iš pradžių (CPK 45 straipsnio 4 dalis). Taigi tai niekaip neskatina proceso koncentracijos principo, nors pareiga pateisinama būtent šio principo svarba. Pažymėtina ir tai, kad apeliacine tvarka bylą nagrinėjantis teismas, savo iniciatyva nustatęs, jog atsakovas yra netinkamas, tačiau nepaklausęs šalies valios, panaikina sprendimą ir bylą grąžina nagrinėti iš naujo pirmaja instancija ${ }^{21}$, taip dar labiau užvilkinant bylos nagrinejjimą, nors šalis galètų pradėti naują procesą prieš tinkamą šali jau žinodama, kaip jai pasiruošti. Nežinia, ar žmonès vertina teismų uolumą keičiant šalị, tačiau šios pareigos suabsoliutinimas lemia, jog žmonių nuomonė tampa nesvarbi, t. y. „pamirštama“ gauti šalių sutikimą ${ }^{22}$, taip pažeidžiant šalių teisę rungtis, bendraji proceso dispozityvumo principą, neišlaikant nešališkumo reikalavimo.

Taigi, nors proceso įstatymas suteikia teisę pirmos instancijos teismui savarankiškai, bet laikantis proceso taisyklių, spręsti dẻl veiksmų, reikalingų visapusiškam bylos išnagrinèjimui, tačiau jo diskrecija yra apribojama kasacinio teismo suformuota pareiga iki bylos nagrinéjimo iš esmès nustatyti tinkamą šali ir pasiūlyti ją pakeisti. Priešingu atveju konstatuojamas proceso pažeidimas. Toks individualus teisingumo aktas tampa atskiru nuo bendro civiliniame procese ịtvirtinto dispozityvumo principo. Tuomet iškyla klausimas: kuo pagrịstas civilinis ginčas - teismo ar bylos šalies teisėmis ir pareigomis?

Kaip minėta, asmeniui, manančiam, kad jo teisė ar įstatymo saugomi interesai yra pažeisti, laiduojama teisė kreiptis ị teismą. Kol teismas išspręs bylą, ieškovo reikalavimas gali būti ginčijamas, t. y. kilęs teisinis santykis yra ginčytinas, nes nėra aiškus ieškinio pagrịstumas, nèra neginčijamų ịrodymų, kad kreipęsis ị teismą asmuo turi subjektinę teisę, dèl kurios gynybos kreipèsi, neaišku, ar iš tikro yra pažeista jo teisè ir ar teisę pažeidè asmuo, kuris patrauktas atsakovu. Tik tuo atveju, kai byla baigiama įsiteisejjusiu teismo sprendimu, galima konstatuoti, kad ginčas yra išspręstas. Tokiu atveju abejotina, ar ịvedamos naujos taisyklès dèl visa apimančios pagalbos šalinant ieškinio trūkumus, išsamios pagalbos suformuluojant reikalavimus, šalies pakeitimo, leis teismui išlikti nešališku arbitru, ištyrusiu visas aplinkybes ir tik po to priëmusiu sprendimą, kaip tai numato betarpiškumo principas, ịtvirtintas CPK 14 straipsnyje. Ar tokiu atveju nèra laikoma, kad teismas, tik gavęs asmens kreipimąsi, jau turètų turèti viziją apie nagrinėtino

Lietuvos Aukščiausiojo Teismo Civilinių bylų skyriaus teisèjų kolegijos 2009 m. gegužès 19 d. nutartis civilineje byloje $U A B$,Nordic investicija" v. Kauno miesto vyriausiasis policijos komisariatas, bylos Nr. 3K-3-120/2009.

21 Žr., pvz., Lietuvos Aukščiausiojo Teismo Civilinių bylų skyriaus teisejjų kolegijos 2006 m. rugsëjo 11 d. nutartis civilineje byloje N. N. v. UAB ,Lietuva Statoil“, bylos Nr. 3K-3-465/2006.

22 Žr., pvz., Lietuvos Aukščiausiojo Teismo Civilinių bylų skyriaus teisëjų kolegijos 2013 m. gegužès 10 d. nutartis civilineje byloje $R$. S. v. Lietuvos valstybe, bylos Nr. 3K-3-295/2013; Lietuvos Aukščiausiojo Teismo Civilinių bylų skyriaus teisèjų kolegijos $2006 \mathrm{~m}$. rugsëjo $11 \mathrm{~d}$. nutartis civilinejje byloje $N$. N. v. UAB ,Lietuva Statoil“", bylos Nr. 3K-3-465/2006 ir kt. 
ginčo eigą, rezultatą ir parengiamajame posėdyje, nurodinėdamas, kokias reikia nustatyti aplinkybes, ji kreiptų ta linkme, kuria, jo manymu, būtu galima teisingiau išnagrinèti ginčą? Kaip minèta, siūlyti konkrečias įrodinètinas aplinkybes reikia dar nepasibaigus ginčui, t. y. neišklausius šalių bylos nagrinejjimo iš esmès stadijoje. Kyla klausimas: ar tai yra įmanoma neturint išankstinès nuostatos?

Jei vadovaujamès Hume'o oficialiosios moralès kaip išplèstinès simpatijos teorija, tuomet keliama problema yra lengvai išsprendžiama. Anot jo, simpatijos apibendrinimas sukuria bendraji geravališkumą - rūpinimąsi bendrają gerove. Šis procesas konverguojasi į nešališką sprendimą. Tačiau B. Barry mano, kad „Hume'o koncepcijoje nešališkumas implikuoja vienokị ar kitokị utilitarizmą “23, todèl ją kritikuoja, argumentuodamas tuo, kad visuomenejje nèra aiškaus viešosios naudos suvokimo. Be to, būtina, kaip jau minèta, ịvertinti, kad gali nesutapti abipusès naudos ir viešosios naudos principai. Tokiu atveju teismo sprendimas, nors, kaip teisejjas mano, yra pagrịstas bendros naudos rūpesčiu, rizikuoja tapti atskirai traktuojamu individualaus teisingumo aktu.

Būtina įvertinti ir tai, kad teismas, pernelyg laisvai interpretuodamas kooperacijos principą̨ ir ėmęsis siūlyti tikslinti ieškinio dalyką, konkrečias įrodinètinas aplinkybes, bylą išspręs ne pagal tikrąą šalies valią. Taip atsitinka ir tuomet, kai teismas savo nuožiūra pasisako dèl teisiškai reikšmingų faktinių pagrindų, kuriais šalis nesiremia ${ }^{25}$. Tokia situacija negali būti pateisinama teisingumo vykdymu, nes tuomet yra nepasiekiamas proceso įstatymo tikslas, neteisètai ribojama asmens teisẻ laisvai pasirinkti savo teisių gynimo būdą. Akivaizdu, kad tokiu atveju kilęs teisinis konfliktas nėra iš esmės išsprendžiamas $^{26}$. Be to, tokiu teismų aktyvumu suerzinama ne tik visuomenè, bet ir sukeliamas nerimas ir daliai teisinès bendruomenès, todèl pradèta viešai (ir teisininkų pokalbiuose) svarstyti, ar teisinis stabilumas (būtent tai garantuoja teisinis pozityvizmas, kurio atstovai supranta teisę kaip įstatymų leidèjo nurodymus ir kritiškai vertina teisèjų galias interpretuoti tuos nurodymus savo nuožiūra) nèra didesnè vertybè, negu pastangos kiekvieną teisinį ginčą individualizuoti, ,perleisti““ per savaji teisingumo, protingumo ir sąžiningumo suvokimą ${ }^{27}$.

Sociologinè teisès samprata, kuria grindžiama netradicinè teisès koncepcija, siūlo, be kita ko, vertinti priimto teismo sprendimo perspektyvą, atsižvelgiant ị gautą socialinę informaciją ${ }^{28}$. Procedūrinių taisyklių tikslas yra ne tiek grynai vien teisiniais argumentais pagrissto sprendimo prièmimas, tačiau ir informacijos apie ginčo esmę gavimas bei

23 Barry, B., supra note 5, p. 182.

24 CPK 8 straipsnis numato, kad teismas, šio Kodekso nustatyta tvarka bendradarbiaudamas su dalyvaujančiais byloje asmenimis, imasi priemonių, kad byla būtų tinkamai išnagrinèta. Dalyvaujantys byloje asmenys šio Kodekso nustatyta tvarka bendradarbiauja tarpusavyje ir su teismu.

25 Lietuvos Aukščiausiojo Teismo Civilinių bylų skyriaus teisėjų kolegijos $2008 \mathrm{~m}$. gegužès 12 d. nutartis civilineje byloje D. Ž. v. UAB ,, Titlis “, byla Nr. 3K-3-237/2008; Lietuvos Aukščiausiojo Teismo Civilinių bylų skyriaus teisèjų kolegijos $2006 \mathrm{~m}$. gruodžio $11 \mathrm{~d}$. nutartis civilinèje byloje UAB "Pamario sargas “ v. Klaipédos miesto savivaldybé, byla Nr. 3K-3-649/2006 ir kt.

26 Plačiau žr. Petkuviené, R.; Atraškevičiūtė; A.; Petkus, A. Enforcement of Freedom of Assembly in Lithuania and European Union: Legal and Practical Aspects. Jurisprudencija. 2012, 1 (19): 58, 59.

27 Lastauskienè, G., supra note 2, p. 1351.

28 Black, D. Socioligocal Justice. New York, Oxford, Oxford University Press, 1989, p. 20, 68. 
jos vertinimas, kad priimant sprendimą būtų užtikrintas ir socialinio konflikto išsprendimas.

\section{Teismo aktyvumas dispozityviose bylose pagal dvi teisingumo teorijas}

Pripažistama, kad rungimosi principu pagrịstas teismo procesas yra teisèjo nešališkumo garantija ${ }^{29}$. Šalys, neįrodžiusios aplinkybių, kuriomis grindžia reikalavimą ar atsikirtimus i jị, prisiima atsakomybę už proceso baigti. Būtent bylos šalies socialinè atsakomybè lemia pareigą įrodinèti, todèl dispozityvioje byloje teismas išimtinai privalo veikti pagal proceso normas, išlaikydamas formalumą. Pareigos įrodinèti aplinkybes pažeidimas, sudaro pagrindą reikalauti nuostolių atlyginimo, taikyti sankciją, vadovaujantis CPK 95 straipsniu $^{30}$. Kontroliuoti, kad šalys laiku pateiktų ịrodymus, nepiktnaudžiautų procesu, yra teismo pareiga. Teismas už piktnaudžiavimą proceso dalyviams taiko sankcijas, kurios laikytinos specifine procesinio, o ne materialinio teisinio pobūdžio atsakomybès priemone ${ }^{31}$.

Tačiau šiuo atveju susiduriama su pažeidimo fakto konstatavimo problema, kuri kyla dẻl nenuoseklios kasacinio teismo praktikos, atsirandančios kuomet remiamasi skirtingomis teisingumo koncepcijomis. İstatymas numato, kad ieškinyje turi būti nurodyta jo suma, faktinis ieškinio pagrindas, įrodymai, patvirtinantys ieškovo išdèstytas aplinkybes, ieškovo reikalavimas (ieškinio dalykas) bei tam tikri procesiniai klausimai (CPK 135 straipsnio 1 dalis). Pagal vieną iš Lietuvos Aukščiausiojo Teismo pozicijų, iš esmès ieškinị sudaro du reikalavimai - ieškinio dalykas ir pagrindas ${ }^{32}$. Taigi nereikalaujama nurodyti įrodymų, kurie patvirtintų ieškovo išdèstytas aplinkybes. Tokiu atveju tampa neįmanoma patikrinti, ar apskritai ginčijama teisė priklauso asmeniui, nors toks reikalavimas, kaip jau minèta anksčiau, pirmos instancijos teismui yra keliamas. Prašymą nurodyti įrodymus kasacinès instancijos teismas aiškina kaip neleistiną teisès nor-

29 Lietuvos Respublikos civilinio proceso komentaras. I dalis. Justitia, Vilnius, 2004, p, 79.

30 CPK 95 straipsnio 1 dalis numato, kad dalyvaujantis byloje asmuo, kuris nesąžiningai pareiškè nepagrịstą ieškinį (apeliacinị ar kasacinị skundą, prašymą atnaujinti procesą, pateikẻ kitą procesinį dokumentą) arba sąmoningai veikè prieš teisingą ir greitą bylos išnagrinejjimą ir išsprendimą, gali būti teismo ịpareigotas atlyginti kitam dalyvaujančiam byloje asmeniui šio patirtus nuostolius. Pagal minėto straipsnio 2 dalị teismas gali paskirti dalyvaujančiam byloje asmeniui iki dvidešimt tūkstančių litų baudą, nustatęs piktnaudžiavimo procesu atveji

31 Valančius, V.; Brazkeikis, A. Kitoks požiūris ị nuostolius dèl piktnaudžiavimo civiliniu procesu. $J u$ risprudencija. 2011, 18 (4): 1084.

32 Lietuvos Aukščiausiojo Teismo Civilinių bylų skyriaus teisejų kolegijos 2013 m. gegužès 10 d. nutartis civilineje byloje Bankrutavusi uždaroji akcinè bendrove ,,Statybu mechanika “ v. restruktūrizuojama akcine bendrove ,,Iglus “ ir kt., bylos Nr. 3K-3-302/2013; Lietuvos Aukščiausiojo Teismo Civilinių bylų skyriaus teisèjų kolegijos $2010 \mathrm{~m}$. vasario 8 d. nutartis civilinejje byloje $R$. B. v. Lietuvos advokatūra, bylos Nr. 3K-3-43/2010; Lietuvos Aukščiausiojo Teismo Civilinių bylų skyriaus teisejjų 2008 m. liepos 10 d. nutartis civilinejje byloje L. Č. v. Kauno apskrities viršininko administracija, bylos Nr. 3K-3-380/ 2008 ir kt. 
mos plečiamaji aiškinimą, kuris riboja teisę kreiptis ị teismą ${ }^{33}$, nes parengiamojo teismo posėdžio metu šalys gali galutinai suformuluoti savo reikalavimus ir atsikirtimų turinį, nurodyti įrodymus. Taigi, jei procesiniame dokumente nėra tokių netikslumų, kurie būtų „staigmena“ atsakovui, procesinis dokumentas privalo būti priimtas. Tačiau, labai sunku spręsti, kas kitai šaliai galètų būtų ,staigmena“. Be to, esant iki galo nesuformuluotam reikalavimui, kita šalis turi pasisakyti dèl visų galimų variantų, rinkti ịrodymus, kurių, kaip vèliau paaiškejja, nereikia. Tuo tarpu net parengiamojo teismo posėdžio metu teismo tenkintas ieškovo prašymas kviesti liudytojus, apie kuriuos jis nė neužsiminė procesiniame dokumente, kitai šaliai sukelia pamąstymus dèl teismo šališkumo, kadangi laikoma, kad pareiga kontroliuoti procesinio dokumento turinio atitikti ịstatymui buvo sąmoningai nevykdoma. Vèliau šis argumentas tampa vienu iš apeliacijos objektų.

Pažymètina ir tai, kad teisès kreiptis ị teismą suabsoliutinimas lemia šalies poziciją pradèti procesą be jokių îrodymų, jų paiešką atliekant bylos nagrinèjimo metu, o teismo siūlymas patikslinti įrodinètinas aplinkybes, nurodant įrodymus, šalies yra traktuojamas kaip teisès kreiptis į teismą ribojimas, jo šališkumas, nukrypimas nuo Lietuvos Aukščiausiojo Teismo praktikos, nors būtent ịstatyme yra numatyta pareiga procesiniame dokumente nurodyti ịrodymus, nes tai lemia valstybinio reguliavimo poreikị, kad procesas nebūtų pradètas be jokio teisinio pagrindo. Toks laisvas įstatymo interpretavimas paskatina piktnaudžiavimą procesu, nes parengiamojo teismo posėdžio metu prašoma išreikalauti ịrodymus, kurie jau turètų būti nurodyti ir pateikiami kartu su procesiniu dokumentu. CPK 112 straipsnio 3 punktas numato, kad procesiniuose dokumentuose, kuriais siekiama pasirengti žodiniam bylos nagrinèjimui, papildomai turi būti ịrodymai, kuriais šalis pagrindžia savo reikalavimus arba atsikirtimus, ir prašymas juos išreikalauti gali būti teikiamas tik tuo atveju, jeigu šalis pati ịrodymų pateikti negali. Tačiau šalys žino, kad pagal kasacinio teismo formuojamą praktiką, šalių rungimosi ir dispozityvumo principus nusveria teismo pareiga tinkamai išnagrinèti bylą ir priimti teisingą sprendimą, išsiaiškinus visas aplinkybes. O šalys, perkèlusios teismui pareigą išreikalauti įrodymus, sutaupo lěšas teisingo bylos išsprendimo sąskaita. Be to, pasitaiko atvejų, kai šalis net apytiksliai nežino, kokie ịrodymai galètų patvirtinti faktines ieškinio aplinkybes, ir spejimo būdu prašo jų išreikalavimo.

Teismui keliama užduotis išsiaiškinti visas aplinkybes yra įveikiama, tačiau ji tampa sunkiai suderinama su įstatymo reikalavimu - bylą išnagrinèti per kuo trumpesni laiką, užtikrinti, kad nebūtų vilkinamas bylos išnagrinèjimas, siekiant, kad civilinè byla būtų išnagrinèta per vieną teismo posèdị (CPK 7 straipsnio 1 dalis, 72 straipsnio1 dalis). Kai parengiamasis teismo posėdis yra skiriamas prašymams dẻl ịrodymų surinkimo, akivaizdu, kad juos gavus bylos nagrinèjimas kitame teismo posèdyje nèra įmanomas. Tuomet, kaip teisingai nurodo M. L. Stormas, teismas gali būti puikus bendrininkas ir pagalbininkas piktnaudžiaujančiai procesinèmis teisėmis šaliai ${ }^{34}$. Toks požiūris ị teisin-

33 Lietuvos Aukščiausiojo Teismo Civilinių bylų skyriaus teisèjų kolegijos $2008 \mathrm{~m}$. liepos 10 d. nutartis civilinejje byloje $L$. $\check{C}$. ir J. J. v. Kauno apskrities viršininko administracija, Kauno rajono savivaldybè, $V$. A., A. B., V. B., Z. M. B. ir kt., bylos Nr. 3K-3-380/2008.

34 Storme, M. L. Over het tergend geding voor een roekeloze vriendschap. Liber Amicorum Jan Ronse. [interaktyvus]. Brussel: Story-Scientia1986, par. 19 [žiūrèta 2009-05-07]. <www.jura.be>. 
gumo vykdymą yra būdingas teisiniam individualizmui, kuris pagrịstas konsumerizmu, juo atsisakoma standartinio teismo proceso, o išeities tašku tampa išplèstinès simpatijos teorija. Būtina įvertinti ir tai, kad priklausomai nuo to, kokius teisèjas savo nuožiūra rinks įrodymus, siekdamas išsiaiškinti bylos aplinkybes, skirsis teismų priimti sprendimai. Nes teisèjui imant laisvai veikti, turi įtakos jo paties interesas dèl simpatijos buvimo ar nebuvimo, pagrịsto empirine patirtimi. Koks tuomet tampa santykis tarp teisingumo ir nešališkumo? Todẻl iškyla klausimas, ar tai nėra spekuliatyvi proceso rekonstrukcija?

Tačiau esant toms pačioms proceso normoms egzistuoja ir kitoks CPK 135 straipsnio 1 dalies aiškinimas. Pavyzdžiui, Lietuvos Aukščiausiasis Teismas 2009 m. balandžio 27 d. nutartyje konstatavo, jog asmuo, pareiškiantis ieškini, , privalo aiškiai suformuluoti jo dalyką ir pagrindą, t. y. išdèstyti aplinkybes, pagrindžiančias jo reikalavimą, bei nurodyti jas patvirtinančius įrodymus. Ieškovas, negalèdamas pateikti ịrodymų, pateikia teismui prašymą juos išreikalauti, nurodydamas negalëjimo pateikti priežastị ${ }^{635}$. Tokia pozicija yra nuosekli aiškinimo tąsa požiūrio, jog teismas privalo patikrinti, ar besikreipiantis ị teismą asmuo nesiekia ịgyvendinti subjektinę teisę nesąžiningai naudodamasis jam suteikta teise, nepiktnaudžiauja procesu, t. y. teisę kreiptis ị teismą nepanaudoja priešingai jos paskirčiai.

Sutiktina su nuomone, kad formalių reikalavimų procesiniam dokumentui nustatymas dar nereiškia, kad yra dirbtinai suvaržyta asmens konstitucinè teisė kreiptis ị teismą ar nepagristai apsunkintas šios teisès igyvendinimas ${ }^{36}$. Galima pasvarstyti ir taip, kad įrodymų nurodymas ne apsunkina asmens teisès igyvendinimą, o paskatina apsvarstyti materialinès teisès gynybos aspektus.

Naujų taisyklių formulavimas pagal faktinę situaciją, pernelyg laisvai interpretuojant proceso normas, sukelia painiavą ne tik pirmos instancijos teismams, o ką kalbėti apie žmones, esančius toli nuo teisinės praktikos. Nebeaišku, ką daryti draudžia teisė, o teisėjų pozicijos nenuoseklumas sukelia nepasitikejjimą teismu. Bet kuriuo atveju, nepagrịstai laisvas teisés akto reikalavimų interpretavimas turi ịtakos bylos nagrinèjimo trukmei, o ilgas teisminis procesas nèra pateisinamas, nes žmogaus teisių gintis tampa neveiksminga. Europos Žmogaus Teisių Teismas bylose prieš Lietuvą dẻl pernelyg ilgos procesų trukmės ne kartą yra pakartojęs, kad bylos nagrinėjimo trukmės pagrịstumas turi būti vertinamas bylos aplinkybių kontekste ir atsižvelgiant ị bylos sudètingumą, pareiškèjo ir atitinkamų valstybès institucijų elgesị $i^{37}$. Kaip minèta, teismas neturètų tapti bendrininku ir pagalbininku piktnaudžiaujančiai procesinėmis teisėmis šaliai. Teisminès praktikos nuoseklumas, vengiant vidinių prieštaringumų, yra didelè vertybè, nes sudaro prielaidas teisinių santykių stabilumui. Proceso teisei yra labai svarbus doktrininis pagrindimas ${ }^{38}$, todèl jo nesant ir nustatant individualias tam ginčui teisines taisykles

35 Žr., pvz., Europos Žmogaus Teisių Teismo 2009 m. liepos 7 d. sprendimas byloje Padalevičius prieš Lietuva, pareiškimo Nr.12278/03; Europos Žmogaus Teisių Teismo 2009 m. sausio 20 d. sprendimas byloje Četvertakas ir kiti prieš Lietuva ir kt., pareiškimo Nr. 16013/02.

36 Abramavičius, A. Teisè ị teisminę gynybą Lietuvos Respublikos Konstitucinio Teismo jurisprudencijoje. Jurisprudencija. 2009, 3 (117): 25.

37 Plačiau žr. Petkuvienè, R.; Atraškevičiūtè, A., supra note 26, p. 1623-1639.

38 Kūris, E. Konstitucinès justicijos proceso teisès klausimu. Teisè. 2011, 78: 21. 
kyla rizika, kad teismai netinkamai pasinaudos jiems suteikta kompetencija. Tuomet iškyla klausimas, kam yra skirtas teisingumas?

\section{Viešosios naudos principai ir teismo vaidmuo}

Teisès principai įtvirtina tam tikrą vertybę, siekiamybę, tikslą. Visus teisinio imperatyvo vykdyti teisingumą aspektus būtų sunku išvardinti. Tačiau jei teisingumo (apimant ir nešališkumą) principo struktūrą dèliotume į nuoseklią ir logišką visumą, gautume daugmaž objektyvų jo turinį. Kai kurių kategorijų bylose nevienodas procesinių teisių ir pareigų pusiausvyros nustatymas įstatyme siejamas su teisingumo ịgyvendinimu. Tuo pagrindžiamas skirtingas dispozityvumo civiliniame procese laipsnis ir teismo vykdoma šalių laisvès kontrolè. Šioje straipsnio dalyje siekiama analizuoti teismo kontrolès ir nešališkumo santykio diskutuotinus aspektus, remiantis kai kuriais praktiniais bylų sprendimo pavyzdžiais.

Reikalavimas imtis griežtesnių apsaugos priemonių, siekiant apsaugoti vartotojų teises, yra Bendrijos politikos ir veiklos kryptis. Šiai politikai yra paveiki ir teismų praktika; priimta teisine pozicija tampa ginčo sprendimo pateisinimo priemone, taip ịvyksta ir proceso rekonstrukcija.

Lietuvos Respublikos civilinio proceso kodeksas iš esmès nenumato jokių specialiu taisyklių, kuriu pagrindu teismas galètų būti aktyvus, kai vartotojas pradeda procesą teisme, išskyrus tai, kad vartotojui yra suteikiamos lengvatos dèl ieškinio pareiškimo vietos ir žyminio mokesčio (vartotojai yra atleisti nuo rinkliavos valstybei). Tačiau pagal kasacinio teismo suformuotą taisyklę, teismas privalo identifikuoti vartojimo sutartis, nes jos yra susijusios su viešojo intereso apsauga, ir dèl jų sąlygų pasisakyti ex officio, net ir tuo atveju, jei šalis nesiremia vartojimo sutarties sudarymo faktu ir neprašo teismo svarstyti ginti jos teises kitu būdu, nes jau pasirinko naudingiausią pažeistos teisès gynybos būdą, kaip tai numato materialinès teisè normos. Taigi teismas yra ịpareigotas atidžiau kontroliuoti šalių veiksmus procese, būti aktyvus, siūlyti vartotojui įrodinètinas aplinkybes, savo iniciatyva rinkti ịrodymus, siekiant užtikrinti, kad vartotojo teisių gynimo būdas būtų tinkamas, parinkti ir taikyti proporcingą bei adekvatų vartotojo teisių gynimo būdą ${ }^{39}$. Šios taisyklès ịvedimas pagrịstas formuojamu požiūriu ị vartotoją, kaip silpnesnę sutarties šalị, kurios teisių gynyba yra prioritetas tiek pagal Europos Sajungos, tiek pagal nacionalinès teisès aktus ${ }^{40}$.

39 Lietuvos Aukščiausiojo Teismo Civilinių bylų skyriaus teisèjų kolegijos $2013 \mathrm{~m}$. balandžio 26 d. nutartis civilineje byloje J. P. v. UAB ,Skytech.lt“, bylos Nr. 3K-3-252/2013; Lietuvos Aukščiausiojo Teismo

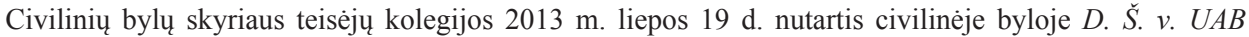
„Borgalita“, BUAB „Kardera“, bylos Nr. 3K-3-406/2013; Lietuvos Aukščiausiojo Teismo Civilinių bylų skyriaus teisëjų kolegijos $2009 \mathrm{~m}$. gegužès 12 d. nutartis civilinèje byloje $D$. Ž. v. UAB "Titlis “, Marijampolès apskrities viršininko administracija, bylos Nr. 3K-3-237/2008. Tesimu praktika. Lietuvos Aukščiausiojo Teismo biuletenis. 30: 345.

40 Vilniaus apygardos teismo Civilinių bylų skyriaus teisèjų kolegijos $2012 \mathrm{~m}$. vasario $1 \mathrm{~d}$. nutartis civilinëje byloje P. L. v. SI ,,Susisiekimo paslaugos “, bylos Nr. 2A-847-520/2012. 
Šiuo atveju gali iškilti kausimas: o jei asmuo nenori, kad jo interesai būtų ginami teismo iniciatyva pagal teisèjo parinktą gynimo būdą? Tokiu atveju kyla rizika, kad teismo ịvykdytu teisingumu bus nepatenkintos abi šalys ir dispozityvumo taisyklès netaikymas padarys daugiau žalos nei duotų naudos, nes tokiu atveju kils dar daugiau nesutarimų (tuomet jau abi šalys naudojasi teise ị apeliaciją, o teisinis konfliktas aštrèja). Taigi išimties iš bendrosios taisyklès taikymas nebeturi akivaizdaus pranašumo. Čia galima pateikti pavyzdị. Civilinè byla buvo pradèta vartotojo iniciatyva dẻl vežimo sutarties viešuoju transportu. Pirmos instancijos teismas sprende, kad ieškovo (vartotojo) teisès jo prašomu būdu negali būti apgintos, nes nèra pagrindo ịpareigoti vežèją vykdyti sutartị, todèl jo reikalavimą atmetè. Apeliacinès instancijos teismas sprendimą panaikino, nurodydamas, kad byloje nèra nustatyta ir išaiškinta, ar ieškovui sumokẻjus pinigus už vežimą ir nepasinaudojus vežimo paslauga dẻl to, kad bilietai yra pripažinti negaliojančiais, nebuvo pažeistos ieškovo teisès ir ar jos neturi būti ginamos kitokiu būdu, nei kad prašo jas apginti ieškovas, bei bylą grąžino nagrinèti iš naujo į pirmają instanciją. Iš naujo pradejjus nagrinèjant bylą, ieškovas atsisakè teismo siūlomų bet kokių kitų galimų jo teisių gynimo būdų, paaiškindamas, kad palaiko tik savo suformuluotą reikalavimą ${ }^{41}$. Taigi siekis, paremtas priimta teisine pozicija dèl vartotojo ginties, išspręsti bylą teisingai liko neigyvendintas, o pareiga užtikrinti operatyvesnị teismo procesą bei apsaugoti Žmogaus teisių ir pagrindinių laisvių apsaugos konvencijos 6 straipsnio 1 dalyje kaip vieną iš pagrindinių žmogaus teisių įtvirtintą teisę ị bylos išnagrinèjimą teisme per ịmanomai trumpiausią laiką nebuvo įvykdyta.

Laikoma, kad teisès ị teisingą teismą ịgyvendinimas neatskiriamas nuo teisès byloje naudotis teisine pagalba, jog asmuo galètų tinkamai ginti pažeistas ar ginčijamas savo teises ir ịstatymų saugomus interesus. Asmenims, turintiems teisę gauti valstybès garantuojamą teisinę pagalbą, ši pagalba teikiama valstybės garantuojamos teisinės pagalbos įstatymo nustatytais atvejais ir tvarka (CPK 99 straipsnio 1 dalis), o valstybés garantuojamą teisinę pagalbą teikia advokatai. Teismas taip pat turi pareigą pasiūlyti šaliai pasirūpinti tinkamu atstovavimu procese (CPK $162^{2}$ straipsnio 1 dalis). Taigi asmuo, kreipęsis ị teismą, yra laisvas spręsti, ar jam reikalinga profesionali pagalba, pasinaudoti ar ne siūlymu turèti advokatą. Bet kuriuo atveju, jei asmuo dèl blogos turtinès padèties neišgali sumokèti už teisines paslaugas, pagalba yra garantuojama valstybès.

Teisminejje praktikoje aplinkybė, jog šalis bet kada gali naudotis advokato pagalba ar yra jo atstovaujama, paprastai reikalavimo teismui būti aktyviam esmés nekeičia. Teismų yra išaiškinta, kad nors kilęs ginčas yra privataus pobūdžio, o šalys naudojosi kvalifikuota teisine pagalba, teismas, siekdamas proceso koncentracijos bei kooperacijos principų tinkamo ịgyvendinimo, privalo išaiškinti, kokiu būdu asmens teisès gali būti apgintos, ir pasiūlyti patikslinti savo ieškinio reikalavimus ${ }^{42}$.

41 Vilniaus apygardos teismo Civilinių bylų skyriaus teisẻjų kolegijos $2012 \mathrm{~m}$. vasario $1 \mathrm{~d}$. nutartis civilinėje byloje P. L. v. SI ,,Susisiekimo paslaugos “, bylos Nr. 2A-847-520/2012.

42 Lietuvos Aukščiausiojo Teismo Civilinių bylų skyriaus teisèjų kolegijos $2012 \mathrm{~m}$. vasario 12 d. nutartis civilineje byloje $V . D . v$. V. U., V. U., V. Ž., I. Ž., A. D., bylos Nr. 3K-3-51/2012; Lietuvos apeliacinio teismo Civilinių bylų skyriaus teisèjų kolegijos $2009 \mathrm{~m}$. gruodžio $21 \mathrm{~d}$. nutartis civilinèje byloje $R$. T. v. V. K., bylos Nr. 2A-675/2009. 
Reikètų pasvarstyti, ar gali teismas būti nešališkas ir neutralus, kai traktuojama, jog asmens interesai turi būti ginami teismo iniciatyva, net ir tuo atveju, jei jis bylą veda per advokatą. Bendrinėje kalboje žodis ,ginti“ reiškia įrodinėti savo nuomonę, savo teiginius, užstoti ${ }^{43}$. Jei teismas gina, tarkim, vartotoją, jis perima jo asmens dalies procesinių teisių ir pareigų igyvendinimą, taip darydamas poveikị pusiausvyros principo užtikrinimui. Kad ir kaip mąstytume, teismui neįmanoma išlikti nešališkam, jei jis turi nurodyti ieškovui, kaip reikšti ieškinį, kad pažeistų teisių gynimo būdas sukeltų teisines pasekmes. Atsakovui tampa akivaizdžiai aišku, kad yra bendradarbiaujama su ieškovu, siekiant užtikrinti būtent jo teisių apsaugą. Tuo tarpu pagal sukurtą teisinę sistemą, asmens teisių tinkama gynyba teisme turètų pasirūpinti advokatas. Jam tinkamai nevykdant šios pareigos, turètų būti sprendžiamas advokato atsakomybės klausimas. Teismas neturètų atstovauti kam nors, nepriklausomai nuo bet kokių sąsajų ${ }^{44}$.

Šioje situacijoje mums reikia konvencijos, leidžiančios teismui būti aktyviam, užtikrinat vartotojo teisių apsaugą, galinčio pateisinti išimtị iš bendrosios dispozityvumo taisyklès, kadangi reikalavimas dèl vartotojo teisių ginties, kai jis pradedamas taikyti atvejui byloje, tampa konkrečia pagalba. Tačiau kaip parodè teismų praktika, tokios konvencijos nèra, ir šalys nuolat kelia ginčą, įrodinèdamos neteisingą įrodinèjimo pareigos paskirstymą, teismo šališkumą. Teismas vis dar yra įsivaizduojamas per simbolị Temidę, ant kurios akių esantis raištis išreiškia vieną pagrindinių taip pat ir šiuolaikinio teisinio teisingumo simbolị - nešališkumą: ,vyras ar moteris, turtingas ar vargšas, galingas ar silpnas - pirmoji nešališkumo pakopa reikalauja taisykles visiems taikyti vienodai: visi prieš įstatymą yra lygūs ${ }^{\text {‘645. }}$.

Tačiau ar tikrai reikia veikti kitaip nei pagal standartinị teismo procesą, preziumuojant, kad materialinès teisès normos yra nepakankamos, neleidžiančios pasiekti teisingo teisinio rezultato. Lietuvos Respublikos civilinis kodeksas (toliau - CK) numato galimybę sudarytas sutartis vertinti pagal CK 6.188 straipsnyje nustatytus sąžiningumo kriterijus, o teismas turi teisę savo iniciatyva pripažinti vartojimo sutarties sąlygas nesąžiningomis. Taip pat įstatyme yra įtvirtinta ne tik contra proferentem aiškinimo taisyklè (CK 6.193-6.195 straipsniai), bet ir speciali CK 6.193 straipsnio 4 dalyje, CK 6.188 straipsnio 6 dalyje ịtvirtinta palankiausio vartotojo atžvilgiu sutarties sąlygos aiškinimo taisyklè. Manytina, kad teismo atliekama šalių veiksmų kontrolè neturètų būti vykdoma padėties pranašumo aspektu, o apsiriboti materialinių teisinių santykių suteiktomis galimybėmis, nes spekuliatyvi proceso rekonstrukcija gali tapti visuomenès nesugyvenimo prielaida, neskatinti socialinio kompromiso paieškos.

Tačiau proceso įstatymo laisvas interpretavimas nereiškia, kad yra nepakankamas įstatymo reguliavimas ir ji reikia keisti. Tereikia jam pateikti pakankamą doktrininị pagrindimą ir suteikti laiko nuoseklios praktikos susiformavimui. Šiame kontekste būtų galima paminèti kelias kasacinio teismo nutartis, aiškinant ịstatymo nuostatas, kad darbo bylą nagrinejjantis teismas turi teisę savo iniciatyva rinkti įrodymus, kuriais šalys nesiremia, jeigu jis mano, jog tai yra būtina siekiant teisingai išspręsti bylą (CPK 114 straips-

43 Dabartinès lietuvių kalbos žodynas [interaktyvus]. [žiūrèta 2013-08-07]. <http://dz.lki.lt/>.

44 Schrag, L. Ethical problems in the practice of law. Aspen Publishers, 2008, p. 589, 590.

45 Höffe, O., supra note 5, p. 11. 
nio 1 dalis), taip pat viršyti pareikštus reikalavimus ir taikyti ịstatymuose numatytą alternatyvų darbuotojo teisių ar teisėtų interesų gynimo būdą (CPK 114 straipsnio 3 dalis). Lietuvos Aukščiausiasis Teismas 2006 m. sausio 4 d. nutartyje išaiškino, jog darbuotojas darbo santykiuose paprastai yra silpnesnè teisinių santykių šalis ${ }^{46}$, tačiau vẻliau, t. y. $2011 \mathrm{~m}$. balandžio 12 d. nutartyje, buvo konstatuota, kad „DK nėra ịtvirtintų nuostatų, kurių pagrindu darbuotojas turètų būti traktuojamas silpnesniaja darbo teisinių santykių šalimi, taigi, dominuoja darbo sutarties šalių lygybès principas (DK 2 straipsnio 1 dalies 4 punktas, 15, 16 straipsniai). Teisiniame reguliavime darbuotojui palanki išimtis yra tik ta, kad esant norminių darbo teisès aktų nuostatų prieštaravimams taikoma darbuotojui naudingesnè nuostata (DK 11 straipsnis 2 dalis) ${ }^{647}$. Taip pat kasacinis teismas keitė požiūri ir į CPK 414 straipsnio 1 dalyje reglamentuotą teismo teisę darbo bylose rinkti įrodymus, nurodydamas, kad teismui suteikta teise būti aktyviam, negali būti aiškinama tokiu būdu, jog atleidžia proceso šalis nuo ịrodymų pateikimo ir argumentų nurodymo ${ }^{48}$. Taigi sugrižtama prie konstruktyviojo teisingumo modelio.

\section{Teisinės metodologijos reikšmė teismų praktikoje}

Teisès mokslininkai ištyrè, jog šiuo metu vyksta bendrosios teisès ir civilinès teisės sistemų konvergencija, kuri teismuose atsiskleidžia per bylų faktų analizę ${ }^{49}$. Galima spręsti, kad viena iš šio proceso priežasčių yra metodo, kuris leistų priimti teisingą sprendimą, paieška. Realistinè teisinè metodologija atskleidžia, kad nėra įmanomas teisinių sprendimų absoliutus tikrumas ir teisingumas. Tačiau teisinès metodologijos išmanymas ir paisymas yra viena iš nuoseklios teismų praktikos formavimosi sąlygų.

Civiliniame procese teisèjas turi daug svarbių pareigų, todèl jam įstatymas suteikia tam tikrą veiksmų laisvę. Asmeniui pradėjus procesą, teisėjas turi dvi labai atsakingas užduotis: 1) užtikrinti asmens teisès kreiptis į teismą igyvendinimą, t. y. objektinès teisès virtimą subjektine, 2) patikrinti, ar kreipimasis nèra inicijuotas be pagrindo, nes kita i procesą įtraukta šalis taip pat turi teises, kurių pagarbą privalo užtikrinti teismas. Suprantama, kad teisminis procesas sukelia ne tik rūpesčius ir nemalonius išgyvenimus; jis, pirmiausia, yra susijęs su materialiniais nuostoliais, kainuoja ir taip brangų laiką. Teisininkas užima tarpinę padètị tarp politinèje valdžioje esančio įstatymų leidèjo ir visuomenès, kaip teisès klientas ${ }^{50}$. Teisejjas, kaip teisès klientas, yra saistomas teisès, todèl jo atliekama teisès akto interpretacija turi būti nekeičianti teisès akto esmès, nesudaryti

46 Lietuvos Aukščiausiojo Teismo Civilinių bylų skyriaus teisejjų kolegijos $2006 \mathrm{~m}$. sausio 4 d. nutartis civilineje byloje Ieškovés A. K. v. AB , Vievio paukštynas “, bylos Nr. 3K-3-10/2006.

47 Lietuvos Aukščiausiojo Teismo Civilinių bylų skyriaus teisèjų kolegijos $2011 \mathrm{~m}$. balandžio 12 d. nutartis civilinejje byloje Ieškovès D. V. K. v. UAB ,Autrolis “, bylos Nr. 3K-3-176/2011.

48 Lietuvos Aukščiausiojo Teismo Civilinių bylų skyriaus teisèjų kolegijos 2013 m. birželio 12 d. nutartis civilinejje byloje Ieškovès S. L. v. viešoji istaiga „Karoliniškiu poliklinika“, bylos Nr. 3K-3-329/2013.

49 Prumm, P. H. The Didactic Turn of German Legal Methodology. Jurisprudencija. 2011, 18 (4): 1258, 1259.

50 Deflem, M. Sociology of Law. Visions of a Scholarly Tradition. Cambridge University Press, 2008, p. 184. 
prielaidų teismo šališkumui ir neobjektyvumui. Aiškaus metodo buvimas teismų praktikoje leistų išvengti vadovavimosi skirtingomis teisès koncepcijomis, t. y. skirtingo teismo sprendimo argumentavimo esant panašioms aplinkybėms, neleistų spekuliuoti priimta teisine pozicija, atsisakant teisinio argumentavimo. Jeigu šio reikalavimo nèra paisoma, vadinasi, nèra teisingumo vykdymo, kurị įtvirtina Konstitucija. Teismų praktika turi būti nuspèjama, žmonès turi teisę žinoti, kokiais argumentais remdamasis teismas sprendžia vieną ar kitą ginčą dèl teisès ${ }^{51}$.

Taip pat iškyla klausimas, ar dviejų teisingumo koncepcijų taikymas teismų praktikoje nėra patogus, siekiant ịgyvendinti teisingumą pagal faktinę situaciją, pagrịstą teismui priimtina bylos baigtimi. Kita vertus, pagal Hume‘ą, tai nėra šališkumas, nes išplèstinès simpatijos koncepcija savaime nèra ydinga. Tuomet laikytume, kad problema atsiranda tik tuomet, kai numanoma bylos baigtis, kuri gali būti skirtinga nuo reliatyvaus teismų požiūrio ị teisingumą, nesutampa su žmogaus poreikiu, nes teismo aktyvumas, pagrịstas gerais siekiais ir viešu interesu, žmogui tampa nereikalingas. Tačiau tuomet yra atsakoma ị klausimą, kodèl toks mažas pasitikèjimas teismais Lietuvoje.

Pasak vieno žymaus konstitucionalisto, demokratinės valstybės teisėjas vykdo dvi pagrindines funkcijas: suartina teisę ir visuomenę; saugo Konstituciją ir demokratiją ${ }^{52}$. Viena iš prielaidų šių funkcijų ịgyvendinimui - visuomenès pasitikèjimas teismais. Jis yra negalimas, kai vyksta teismų blaškymasis tarp teisingumo teorijų, kuris yra neleistinas žmogaus teisių atžvilgiu.

\section{Išvados}

1. Nešališkumo standartas pasiekiamas, jei laikomasi vieno atskaitos taško, t. y. tuomet, kai visų elgesys yra saistomas tam tikrų universaliai taikomų taisyklių. Padidèjus teismo aktyvumui, jam pradejus laisvai interpretuoti teisès normas, visuomenè turi modifikuoti arba pritaikyti įsitikinimus dẻl laisvesnio taisyklių taikymo.

2. Kiekvieno teisinio ginčo individualizavimas pagal naujai sukurtas (alternatyvias, grindžiamas prielaida, kad standartinis teisminis procesas nėra pakankamas teisingumo igyvendinimui) proceso taisykles sukuria prielaidas teisiniam nestabilumui.

3. Individo apsaugos reikalavimu grindžiamas požiūris paskatina atsisakyti universaliai taikomų taisyklių. Tokia teisingumo koncepcija būdinga teisiniam individualizmui, kuris pagrịstas konsumerizmu, juo atsisakoma standartinio teismo proceso, o išeities tašku tampa išplèstinès simpatijos teorija.

4. Nesant naujų suformuotų proceso taisyklių doktrininio pagrindimo, kyla rizika, kad teismai netinkamai pasinaudos jiems suteikta diskrecija, tuomet nebus pasiektas teisingumo igyvendinimas.

51 Jarašiūnas, E. Valstybès valdžios instituciju santykiai ir Konstitucinis Teismas. Vilnius: Teisinės informacijos centras, 2003, p. 88-90.

52 Barak, A. Teisèjo vaidmuo demokratinejje valstybejje. Konstitucinè jurisprudencija. 2006, 1: 292-297. 
5. Teisinès metodologijos išmanymas ir paisymas yra viena iš nuoseklios teismų praktikos formavimosi sąlygų. Aiškaus metodo (skirtingo teismo sprendimo argumentavimo esant panašioms aplinkybėms) buvimas teismų praktikoje leistų išvengti vadovavimosi skirtingomis teisès koncepcijomis, neleistų spekuliuoti priimta teisine pozicija, atsisakant teisinio argumentavimo.

6. Teisèjas, kaip teisès klientas, yra saistomas teisès, todèl jo atliekama teisès akto interpretacija turi būti nekeičianti teisès akto esmès, nesudaryti prielaidų teismo šališkumui ir neobjektyvumui.

\section{Literatūra}

Abramavičius, A. Teisè ị teisminę gynybą Lietuvos Respublikos Konstitucinio Teismo jurisprudencijoje. Jurisprudencija. 2009, 3 (117).

Barak, A. Teisèjo vaidmuo demokratinejje valstybèje. Konstitucine jurisprudencija. 2006, 1.

Barry, B. Teisingumo teorijos. Vilnius: Eugrimas, 2002.

Black, D. Socioligocal Justice. New York, Oxford: Oxford University Press, 1989.

Deflem, M. Sociology of Law. Visions of a Scholarly Tradition. Cambridge University Press, 2008.

Dworkin, R. Rimtas požiūris ị teises. Vilnius: Lietuvos rašytojų sajungos leidykla, 2004.

Dabartinès lietuviu kalbos žodynas [interaktyvus]. [žiūrèta 2013-08-07]. <http://dz.lki. $1 \mathrm{t} />$.

Europos Žmogaus Teisių Teismo 2009 m. liepos 7 d. sprendimas byloje Padalevičius prieš Lietuva, pareiškimo Nr. 12278/03.

Europos Žmogaus Teisių Teismo 2009 m. sausio 20 d. sprendimas byloje Četvertakas ir kiti prieš Lietuvq ir kt., pareiškimo Nr. 16013/02.

Höffe, O. Gerechtigkeit. München: Beck, 2001. Jarašiūnas, E. Valstybès valdžios instituciju santykiai ir Konstitucinis Teismas. Vilnius: Teisinès informacijos centras, 2003.

Kūris, E. Konstitucinès justicijos proceso teisès klausimu. Teisé. 2011, 78.

Lastauskienè, G. Teisè v. teisè arba teismu ,interpretacinis žaismas" ir jo doktrininès prielaidos. Jurisprudencija. 2012, 19 (4).
Lietuvos Respublikos Konstitucija, Lietuvos Respublikos piliečių priimta $1992 \mathrm{~m}$. spalio 25 d. referendume. Valstybès žinios. 1992, Nr. 33-1014.

Lietuvos Respublikos teismų įstatymas. Valstybès žinios. 1994, Nr. 48-851.

Lietuvos Respublikos civilinio proceso kodeksas. Valstybès žinios. 2002, Nr. 36-1340; Valstybès žinios. 2002, Nr. 42.

Lietuvos Respublikos Konstitucinio Teismo $2001 \mathrm{~m}$. vasario $12 \mathrm{~d}$. nutarimas „Dèl Lietuvos Respublikos advokatūros įstatymo 26 straipsnio 3 ir 4 dalių atitikimo Lietuvos Respublikos Konstitucijai“. Valstybès žinios. 2001, Nr. 14-445.

Lietuvos Aukščiausiojo Teismo Civilinių bylų skyriaus teisèjų kolegijos 2013 m. birželio $12 \mathrm{~d}$. nutartis civilinejje byloje Ieškovès $S$. $L$. v. viešoji ịstaiga ,Karoliniškiu poliklinika“, bylos Nr. 3K-3-329/2013.

Lietuvos Aukščiausiojo Teismo Civilinių bylų skyriaus teisejjų kolegijos $2013 \mathrm{~m}$. liepos 19 d. nutartis civilineje byloje $D . \breve{S}$. v. UAB „Borgalita“, BUAB „Kardera“, bylos Nr. 3K-3-406/2013.

Lietuvos Aukščiausiojo Teismo Civilinių bylų skyriaus teisejų kolegijos 2013 m. gegužès $10 \mathrm{~d}$. nutartis civilinèje byloje $R$. S. v. Lietuvos valstybe, bylos Nr. 3K-3-295/2013.

Lietuvos Aukščiausiojo Teismo Civilinių bylų skyriaus teisejjų kolegijos $2013 \mathrm{~m}$. balandžio 26 d. nutartis civilinèje byloje $J$. P. v. UAB „,Skytech.lt“, bylos Nr. 3K-3-252/2013. 
Lietuvos Aukščiausiojo Teismo Civilinių bylų skyriaus teisèjų kolegijos 2013 m. gegužès 10 d. nutartis civilineje byloje Bankrutavusi uždaroji akciné bendrovè ,Statybu mechanika" v. restruktūrizuojama akciné bendro$v \dot{e}$,Iglus “ ir kt., bylos Nr. 3K-3-302/2013.

Lietuvos Aukščiausiojo Teismo Civilinių bylų skyriaus teisèjų kolegijos 2013 $\mathrm{m}$. vasario $22 \mathrm{~d}$. nutartis civilinejje byloje R. M. v. O. J. M. ir L. V. M., bylos Nr. 3K-3-12/2013.

Lietuvos Aukščiausiojo Teismo Civilinių bylų skyriaus teisejjų kolegijos $2012 \mathrm{~m}$. spalio 31 d. nutartis civilineje byloje $A B$,Panevéžio energija“ v. AB „Diskontas“, bylos Nr. 3K-3-154/2012.

Lietuvos Aukščiausiojo Teismo Civilinių bylų skyriaus teisejų kolegijos $2012 \mathrm{~m}$. vasario 12 d. nutartis civilineje byloje $V . D . v . V$. $U$., $V . U$., $V . \check{Z}$., I. Ž., A. D., bylos Nr. 3K$3-51 / 2012$.

Lietuvos Aukščiausiojo Teismo Civilinių bylų skyriaus teisèjų kolegijos $2011 \mathrm{~m}$. balandžio 12 d. nutartis civilinèje byloje Ieškovès $D$. V. K. v. UAB ,Autrolis“, bylos Nr. 3K-3176/2011.

Lietuvos Aukščiausiojo Teismo Civilinių bylų skyriaus teisèjų kolegijos $2011 \mathrm{~m}$. balandžio 19 d. nutartis civilineje byloje G. L. v. S. D., bylos Nr. 3K-3-186/2011.

Lietuvos Aukščiausiojo Teismo Civilinių bylų skyriaus teisèjų kolegijos $2010 \mathrm{~m}$. vasario 8 d. nutartis civilinèje byloje $R$. B. v. Lietuvos advokatūra, bylos Nr. 3K-3-43/2010.

Lietuvos Aukščiausiojo Teismo Civilinių bylų skyriaus teisejjų $2008 \mathrm{~m}$. liepos $10 \mathrm{~d}$. nutartis civilineje byloje $L$. Č. v. Kauno apskrities viršininko administracija, bylos Nr. 3K-3380/2008.

Lietuvos Aukščiausiojo Teismo Civilinių bylų skyriaus teisèju kolegijos 2009 m. balandžio 27 d. nutartis civilineje byloje $V . K$. v. D. K., Marijampolès apskrities viršininko administracija, bylos Nr. 3K-3-181/2009.

Lietuvos Aukščiausiojo Teismo Civilinių bylų skyriaus teisèjų kolegijos 2008 m. gegužès 12 d. nutartis civilineje byloje $D$. Ž. v. UAB „,Titlis “, byla Nr. 3K-3-237/2008.
Lietuvos Aukščiausiojo Teismo Civilinių bylų skyriaus teisėjų kolegijos $2006 \mathrm{~m}$. rugsèjo 11 d. nutartis civilineje byloje $N . N$. v. UAB „Lietuva Statoil“, bylos Nr. 3K-3-465/2006.

Lietuvos Aukščiausiojo Teismo Civilinių bylų skyriaus teisèjų kolegijos 2006 m. gruodžio 11 d. nutartis civilineje byloje $U A B$,,Pamario sargas “ v. Klaipedos miesto savivaldy$b \dot{e}$, byla Nr. 3K-3-649/2006.

Lietuvos Aukščiausiojo Teismo Civilinių bylų skyriaus teisèjų kolegijos $2006 \mathrm{~m}$. sausio $4 \mathrm{~d}$. nutartis civilinejje byloje Ieškovès $A$. K. v. AB ,,Vievio paukštynas “, bylos Nr. 3K-3$10 / 2006$.

Lietuvos apeliacinio teismo $2009 \mathrm{~m}$. gruodžio 21 d. nutartis civilineje byloje $R . T$. v. V. K., bylos Nr. 2A-675/2009.

Petkuvienè, R.; Atraškevičiūtè, A.; Petkus, A. Enforcement of Freedom of Assembly in Lithuania and European Union: Legal and Practical Aspects. Jurisprudencija. 2012, 1 (19).

Prumm, P. H. The Didactic Turn of German Legal Methodology. Jurisprudencija. 2011, 18 (4).

Rawls, A. Theory of Justice. Cambridge, Mass.: Harvard University Press, 1971.

Rosenberg, L.; Schwab, H. K.; Gottwald, P. Zivilprozessreecht. 15. Aufl. München: Verlag C. H Beck, 1993.

Stauskienè, E. Konstitucinès justicijos ịtaka Lietuvos civilinio proceso teisei. Jurisprudencija. 2012, 19 (3).

Schrag, L. Ethical problems in the practice of law. Aspen Publishers, 2008.

Storme, M. L. Over het tergend geding voor een roekeloze vriendschap. Liber Amicorum Jan Ronse [interaktyvus]. Brussel: StoryScientia, 1986, par. 19 [žiūrèta 2009-05-07]. $<$ www.jura.be $>$.

Valančius, V.; Brazkeikis, A. Kitoks požiūris ì nuostolius dèl piktnaudžiavimo civiliniu procesu. Jurisprudencija. 2011, 18 (4).

Vilniaus apygardos teismo Civilinių bylų skyriaus teisejų kolegijos $2012 \mathrm{~m}$. vasario $1 \mathrm{~d}$. nutartis civilineje byloje $P$. L. v. St ,Susisiekimo paslaugos", bylos Nr. 2A-847520/2012. 


\title{
JUSTICE AND EQUITY WITHIN CIVIL PROCESS
}

\author{
Rūta Petkuvienè
}

Mykolas Romeris University, Lithuania

Summary. The article provides an analysis on how much the standard court proceedings can be regarded as the research, which is performed by investigating by what manner and measures the justice in a procedural sense is implemented. It is generally acknowledged that the court, as a subject, solving a legal dispute, implements justice only in the case, when it ensures the impartiality towards all persons. The appropriate legal proceedings form a constituent part of the constitutional right to apply in the court. The article aims at introducing certain aspects of the implementation of the principle of justice in the court proceedings of Lithuania. It is indicated that the lack of legal methodology results in different arguments of the rendered decisions and their unpredictability, therefore, it does not encourage to opt for the legal peace. The article is topical in a sense that it has not provided an analysis, on which the aspects of impartiality reveal themselves in the nowadays case law in particular cases and how it produces an effect on the approach to justice.

In Lithuania, doctrinal presumptions were created for the freedom of the courts, upon which the courts started to formulate new procedural regulations. The freedom of the actions of judges is based on the aim to ensure a stronger safety in regard to the rights pertaining to one of the public groups, i.e. to disallow the domination of certain subjects over the others by eliminating inequality between the parties. The freedom of the actions of judges is also justified by the aim to render the right decision. However, the formulation of the new regulations according to the actual situation by too freely interpreting the norm of the proceedings, without having the doctrinal basis for that, causes the legal confusion, thus inconsistency in the case law appears, the inner contradictions arise and, in addition to that, there is a failure to follow the standard of impartiality. The individualisation of each legal dispute pursuant to the newly established procedural regulations creates the presumptions for legal instability. Upon the absence of doctrinal substantiation for the newly formulated procedural regulations, the risk arises for the courts to unduly avail of the competence granted to them, thus there will be no implementation of the justice attained.

The approach, based on the demand for an individual safety, encourages to refuse the regulations, which are universally applied. Such conception of justice is characteristic for legal individualism, which is grounded in consumerism, by means of which the standard court proceedings are refused, while the extended sympathy theory becomes the starting point. The comprehension and observance of the legal methodology is one of the conditions for the development of the consistent case law. The presence of a clear method in the case law will allow to prevent from pursuing different legal conceptions, i.e. different reasoning of a court decision upon the similar circumstances, as well as it will prevent from speculating on the accepted legal position by refusing the legal argument.

Keywords: interpretation of law, judicial activity, justice, equity, legalese methodology. 
Rūta Petkuvienė, Mykolo Romerio universiteto Teisès fakulteto Teisès filosofijos ir istorijos katedros lektorè, socialinių mokslų (teisès krypties) daktarè. Mokslinių tyrimų kryptys: teisès teorija, žiniasklaidos teisè, teisès sociologija, teisès aiškinimas.

Rūta Petkuvienė, Mykolas Romeris University, Faculty of Law, Departament of Philosophy and History of Law, Lecturer, Doctor of Social Sciences (Law). Research interests: theory of law, media law, sociology of law, interpretation of law. 